\title{
Effect of ileo-rectal anastomosis and post-valve T-caecum cannulation on growing pigs
}

\author{
2. Blood variables and mineral balances \\ BY T. KÖHLER ${ }^{1,2}$, M. W. A. VERSTEGEN ${ }^{1}$ AND R. MOSENTHIN² \\ ${ }^{1}$ Department of Animal Nutrition, Agricultural University, Haagsteeg 4.6708 PM Wageningen, \\ The Netherlands \\ 'Institute of Animal Nutrition and Feed Science, University of Kiel, D-2300 Kiel, Germany' \\ AND T. WENSING \\ Clinic for Large Animal Medicine, State University of Utrecht, Yalelaan 16, 3584 CM Utrecht, \\ The Netherlands \\ AND L. A. DEN HARTOG \\ Research Institute for Pig Husbandry, PO Box 83,5240 AB Rosmalen. The Netherlands \\ AND J. HUISMAN \\ TNO Institute for Animal Nutrition and Physiology (ILOB), PO Box 15, 6700 AA Wageningen, \\ The Netherlands
}

(Received 8 October 1990-Accepted 1 August 1991)

\begin{abstract}
In a long-term study nine ileo-rectally anastomosed (IRA) and seven post-valve T-caecum (PVTC)cannulated pigs were compared with six intact pigs with regard to different blood variables, sodium and potassium retention and weights of selected organs. After surgery, apart from urea and $K$ measured 13 weeks post-surgery, there were no differences in the blood variables between the PVTC-pigs and intact pigs. In IRA-pigs concentrations of creatinine $(P<0.01), \mathrm{Na}(P<0.001)$, base excess $(P<0.001)$, $\mathrm{pH}$ $(P<0.01)$ and bicarbonate $(P<0.001)$ in blood were lower than those in intact pigs. At 13 weeks after surgery the blood $K$ concentration in IRA-pigs was higher $(P<0.001)$ than that in PVTC-pigs or intact pigs. At 6 weeks after surgery the blood urea concentration in IRA-pigs was higher $(P<0-001)$ than that in intact and PVTC-pigs. At 13 weeks after surgery the urea concentration in PVTC-pigs was higher $(P<0.001)$ than those in IRA-pigs or intact pigs. The Na $(P<0.0111$ weeks after surgery $)$ and $(P<$ 0.05 and $P<0.015$ and 11 weeks after surgery respectively) balances in IRA-pigs were lower than those in intact animals. Na retention was negative for IRA-animals 11 weeks after surgery. Na and $K$ retentions were similar in PVTC-pigs and in intact pigs. The urinary : faecal excretion of Na differed slightly between PVTC-animals and intact animals. At 13 weeks after surgery there were no differences in organ weights between the PVTC-pigs and intact animals. In the IRA-pigs the weights of the liver $(P>0.05)$, the kidneys $(P>0.05)$ and the adrenal glands were higher $(P<0.001)$ than those in the intact animals.
\end{abstract}

Ileo-rectal anastomosis: Post-valve T-caecum cannulation: Blood variables: Na and $\mathrm{K}$ balances: Pig

The post-valve T-caecum (PVTC) cannula, as described by van Leeuwen et al. (1988), has been shown to provide reliable measurements of digestibilities at the distal ileum of pigs (Köhler et al. 1990; Van Leeuwen et al. 1991). Ileo-rectal anastomosis (IRA) has been proposed as an alternative technique for cannulation (Picard et al. 1984; Laplace et al. 
1985; Souffrant et al. 1985; Green, 1988). Both methods may affect the physiological state of the animals. Digestibility as a physiological variable has to be determined in animals in a normal physiological state. Findings for growth performance, digesta flow and intestinal fermentation have been presented previously (Köhler et al. 1992b). The objective of the present study was to compare the recently developed PVTC-cannulation technique with the end-to-side IRA technique with regard to different blood variables, sodium and potassium balances and selected organ weights.

\section{MATERIALS AND METHODS}

Twenty-two crossbred castrates (Yorkshire $\times$ Dutch Landrace) with an average bodyweight of $30 \mathrm{~kg}$ were used. Nine pigs were provided with an end-to-side IRA and seven pigs with a PVTC cannula. Details of surgical techniques and the experimental procedures have been reported previously (Köhler et al. 1992b). The experimental design is shown schematically in Fig. 1. The animals were fed at 2.4 times maintenance requirement for energy (Agricultural Research Council, 1981). The composition of the experimental diet is shown in Table 1.

\section{Blood samples}

At 6 and 13 weeks after surgery blood samples were obtained $3 \mathrm{~h}$ post-prandially by puncture of the external jugular vein. The following analyses in blood were carried out: Na, $\mathrm{K}$, chloride, calcium, magnesium, urea, creatinine, $\mathrm{pH}$, active bicarbonate and the base excess. In addition $\mathrm{Na}$, urea and creatinine levels were determined 1 week before surgery.

\section{Analysis of blood samples}

Urea, creatinine, $\mathrm{Na}, \mathrm{K}$ and $\mathrm{Cl}$ concentrations were measured in serum obtained after centrifugation of the blood samples at $3000 \mathrm{rev} . / \mathrm{min}$ for $20 \mathrm{~min}$.

Urea and creatinine concentrations were estimated using Biomérieux kits. $\mathrm{Na}$ and $\mathrm{K}$ were measured using a flame photometer (model 243, Instrumentation Laboratory, Cheltenham, PA, USA), and $\mathrm{Cl}$ using a Chlor-O-Counter (Laméris Instruments Bv, Utrecht, The Netherlands). Mg was measured in heparinized plasma using an atomic absorption spectrophotometer (model 305 B Perkin Elmer, Pomona, USA). Plasma Ca concentration was measured according to Willis (1960). $\mathrm{pH}$, bicarbonate and base excess were measured in blood, sampled air-free in a syringe, kept at $0^{\circ}$ in ice until analysed using a blood gas pH meter (ABL2 acid base laboratory radiometer, Analytical 175/Medical 175 Bagsvaerd, Copenhagen, Denmark). These analyses were carried out within 90 min of collection of the blood.

\section{$N a$ and $K$ balances}

At 5 and 11 weeks after surgery the $\mathrm{Na}$ and $\mathrm{K}$ balances were determined over a period of $5 \mathrm{~d}$.

\section{Organ weights}

At 13 weeks after surgery the animals were slaughtered and the weights of the liver, kidneys and the adrenal glands as well as the circumference of the rectum were registered.

\section{RESULTS}

Blood variables

Values for blood variables are shown in Table 2. After surgery the blood creatinine contents of pigs fitted with an IRA were significantly lower than those in intact animals or in animals fitted with a PVTC cannula $(P<0.01)$. Pre-operative urea concentrations were not different between the treatment groups. At 6 weeks after surgery urea levels in the IRAanimals were increased and higher $(P<0.001)$ than in the other treatments. At 13 weeks 
Surgery

Blood samples

Nitrogen balances

Potassium and sodium balances

Digesta collections

Organ weights

Live weights

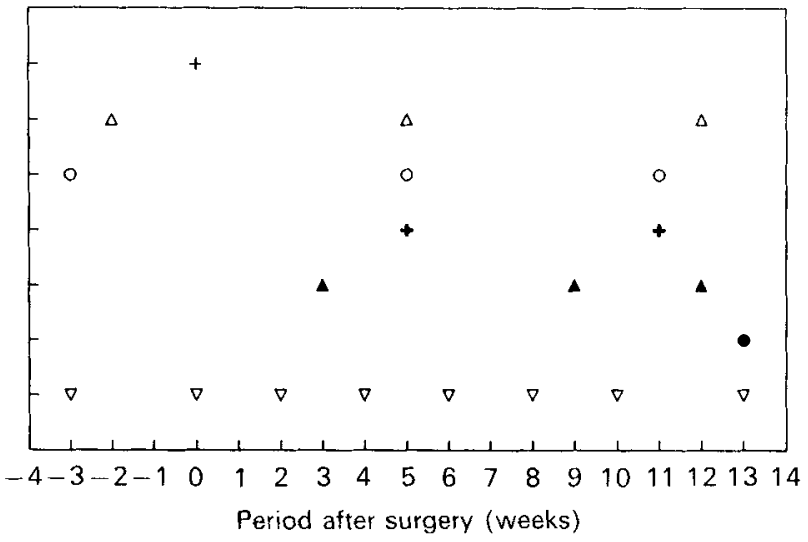

Fig. 1. Experimental design. For details of techniques and procedures, see pp. 306-307.

Table 1. Composition of the experimental diet $(\mathrm{g} / \mathrm{kg})$

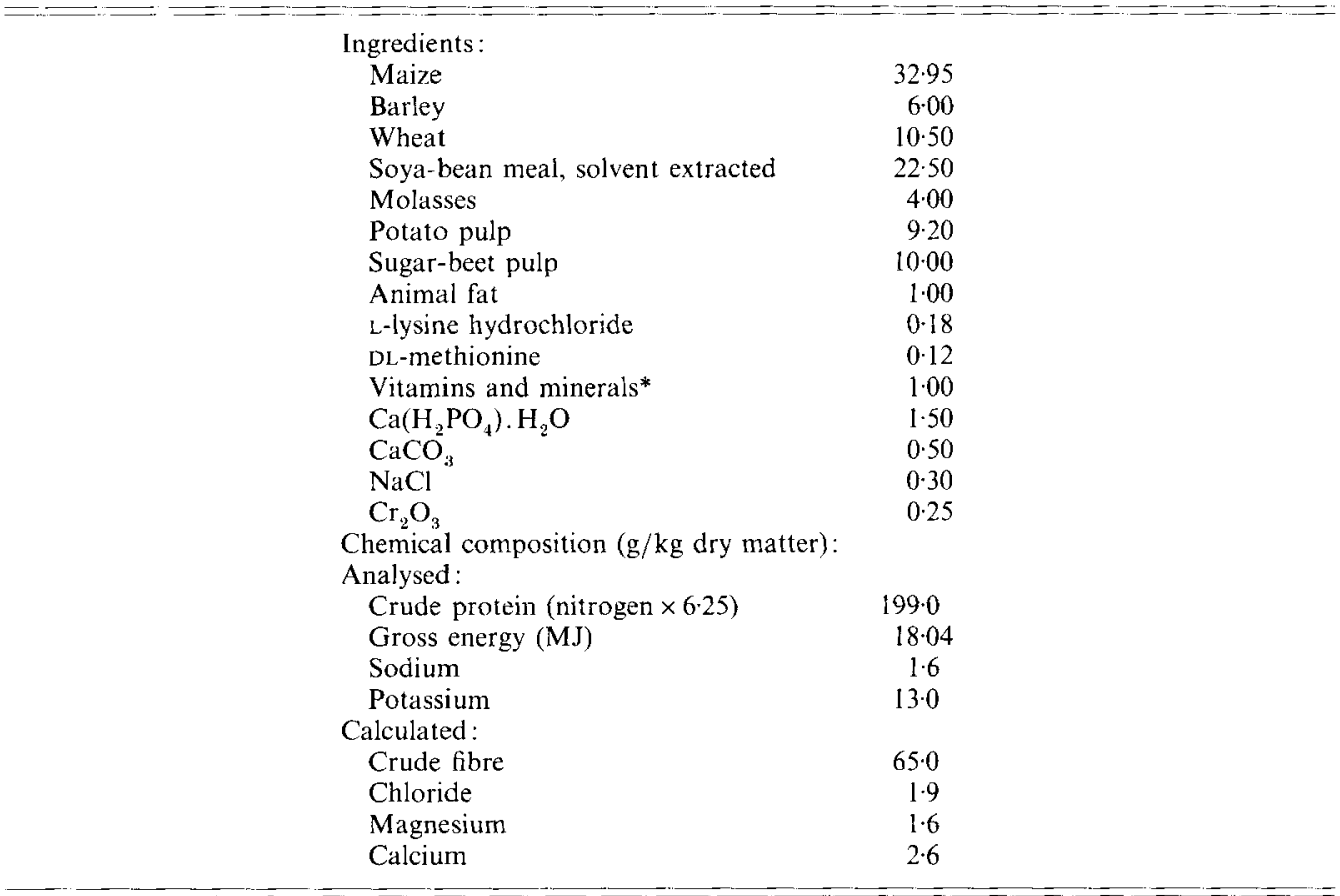

* Contributed (mg/kg diet): retinol 2.7, cholecalciferol $45 \mu \mathrm{g}, \alpha$-tocopherol 40, menadione 3, riboflavin 5 , cobalamine $40 \mu \mathrm{g}$, nicotinic acid 30, D-pantothenic acid 12, choline chloride 150 , ascorbic acid $50, \mathrm{KI} 500 \mu \mathrm{g}$, $\mathrm{CoSO}_{4} .7 \mathrm{H}_{2} \mathrm{O} 2.5, \mathrm{Na}_{2} \mathrm{SeO}_{3} 0.2, \mathrm{FeSO}_{4} .7 \mathrm{H}_{2} \mathrm{O} 0.40 \mathrm{~g}, \mathrm{CuSO}_{4} .5 \mathrm{H}_{2} \mathrm{O} 0.1 \mathrm{~g}, \mathrm{MnO}_{2} 0.07 \mathrm{~g}, \mathrm{ZnSO}_{4} . \mathrm{H}_{2} \mathrm{O} 0.2 \mathrm{~g}$. This mixture also supplied $20 \mathrm{mg}$ virginiamycin $/ \mathrm{kg}$ diet, the mixture was made up to $1 \mathrm{~kg}$ with ground maize.

after surgery blood urea levels for IRA-animals and intact pigs were similar; however, PVTC-cannulated animals had higher $(P<0.001)$ levels compared with those for the other two treatments. At 6 and 13 weeks after surgery the blood $\mathrm{Na}$ levels of IRA-animals were lower than those of the intact animals $(P<0.001$ and $P<0.01$ respectively). At 13 weeks after surgery the blood $\mathrm{K}$ levels of the IRA-pigs were higher than those of the other animals 
Table 2. Biochemical characteristics in serum of pigs with ileo-rectal anastomosis (IRA), post-valve T-caecum (PVTC) cannula or intact intestinal tract

\begin{tabular}{|c|c|c|c|c|c|}
\hline Treatment group... & $\begin{array}{l}\text { Period after surgery } \\
\text { (weeks) }\end{array}$ & IRA & PVTC & Intact & SEM \\
\hline \multirow[t]{3}{*}{ Creatinine $(\mu \mathrm{mol} / \mathrm{l})$} & Presurgery & $112 \cdot 22$ & $124 \cdot 71$ & $111 \cdot 33$ & $4 \cdot 20$ \\
\hline & 6 & 118.78 & $145.71^{* *}$ & 137.00 & $5 \cdot 15$ \\
\hline & 13 & $127 \cdot 11$ & $149 \cdot 7 ! * *$ & $148 \cdot 33^{* *}$ & 4.78 \\
\hline \multirow[t]{3}{*}{ Urea $(\mathrm{mmol} / \mathrm{l})$} & Presurgery & $3 \cdot 75$ & 3.66 & 3.92 & $0 \cdot 19$ \\
\hline & 6 & $6 \cdot 77$ & $3 \cdot 97 * * *$ & $4.53 * * *$ & 0.33 \\
\hline & 13 & 6.02 & $8 \cdot 36 * * *$ & $6 \cdot 37$ & 0.32 \\
\hline \multirow[t]{3}{*}{ Sodium (mmol/1) } & Presurgery & $146 \cdot 78$ & $147 \cdot 57$ & $147 \cdot 17$ & 0.65 \\
\hline & 6 & $140 \cdot 11$ & $150 \cdot 71 * * *$ & $148 \cdot 17^{* * *}$ & 1.34 \\
\hline & 13 & $139 \cdot 33$ & $144 \cdot 71^{* *}$ & $146 \cdot 33^{* *}$ & 1.39 \\
\hline \multirow[t]{2}{*}{ Potassium (mmol/l) } & 6 & $5 \cdot 79$ & $5 \cdot 50$ & 5.00 & 0.25 \\
\hline & 13 & $5 \cdot 61$ & $5.09 * * *$ & $4 \cdot 75 \dagger+\dagger$ & 0.09 \\
\hline \multirow[t]{2}{*}{ Chlorine $(\mathrm{mmol} / \mathrm{l})$} & 6 & $95 \cdot 11$ & 99.86 & 98.50 & 1.37 \\
\hline & 13 & $92 \cdot 22$ & 91.86 & $95 \cdot 00$ & $1 \cdot 31$ \\
\hline \multirow{2}{*}{ Calcium (mmol/l) } & 6 & $2 \cdot 60$ & 2.53 & $2 \cdot 60$ & 0.03 \\
\hline & 13 & $2 \cdot 60$ & 2.53 & $2 \cdot 60$ & 0.04 \\
\hline \multirow[t]{2}{*}{ Magnesium $(\mathrm{mmol} / \mathrm{l})$} & 6 & 0.84 & 0.87 & 0.87 & 0.02 \\
\hline & 13 & 0.83 & 0.90 & 0.85 & 0.02 \\
\hline \multirow[t]{2}{*}{ Base excess $(\mathrm{mmol} / 1)$} & 6 & $1 \cdot 19$ & $3 \cdot 14$ & $5 \cdot 18^{* * *}$ & 0.50 \\
\hline & 13 & -0.96 & $5 \cdot 24^{* *}$ & $6 \cdot 50^{* *}$ & $1 \cdot 37$ \\
\hline \multirow[t]{2}{*}{$\mathrm{pH}$} & 6 & 7.32 & $7 \cdot 31$ & $7 \cdot 37$ & $0 \cdot 41$ \\
\hline & 13 & $7 \cdot 26$ & $7 \cdot 37^{* *}$ & $7 \cdot 38^{* *}$ & 0.03 \\
\hline \multirow{2}{*}{$\begin{array}{l}\text { Active bicarbonate } \\
(\mathrm{mmol} / \mathrm{l})\end{array}$} & 6 & $28 \cdot 63$ & $32 \cdot 37 * * *$ & $32 \cdot 30^{* * *}$ & $0 \cdot 61$ \\
\hline & 13 & 27.89 & $32 \cdot 36^{* *}$ & $33.88 * *$ & 1.04 \\
\hline
\end{tabular}

Mean values were significantly different from those for IRA-pigs: ${ }^{* *} P<0 \cdot 01,{ }^{* *} P<0 \cdot 001$.

Mean values for intact pigs were significantly different from those for PVTC-pigs and IRA-pigs: $\uparrow+\uparrow P<0.001$.

$\ddagger$ For details of techniques and procedures, see pp. 306307 .

$(P<0.001)$. In PVTC-pigs blood $\mathrm{K}$ levels were intermediate relative to the other two treatments and significantly higher $(P<0.001)$ than levels for intact pigs. No significant differences between treatments were observed for the blood $\mathrm{Cl}, \mathrm{Ca}$ and $\mathrm{Mg}$ contents. At 6 weeks after surgery the blood base excess of IRA-pigs was $(P<0 \cdot 001)$ lower than that of intact pigs. The PVTC-animals had intermediate levels between IRA- and intact animals. At 13 weeks after surgery the blood base excess of IRA-pigs was at a very low level and significantly different $(P<0.01)$ from that of the other two treatments. At 13 weeks after surgery serum $\mathrm{pH}$ for IRA-animals differed $(P<0.01)$ from that for the other two treatments. At both 6 and 13 weeks post-operatively the amounts of active bicarbonate for IRA-pigs were lower ( $P<0.001$ and $P<0.01$ respectively) than those for PVTC-pigs and intact pigs.

\section{Na balance}

The results of the $\mathrm{Na}$ balances are given in Table 3. For the intact and PVTC-cannulated pigs the Na retention $(\mathrm{mg} / \mathrm{d})$ decreased with time but remained slightly positive. At 5 weeks after surgery the Na retention $(\mathrm{mg} / \mathrm{d}$ ) of IRA-pigs was in the same range as values obtained for the other treatments. At 11 weeks after surgery the Na balance of the IRA-pigs was lower $(P<0.01)$ than those of the other treatments. At both 5 and 11 weeks the $\mathrm{Na}$ retention of PVTC-animals was similar to that of intact pigs. Table 3 also shows that in intact and PVTC-cannulated animals the amount of $\mathrm{Na}$ excreted in the urine was higher than that excreted in the faeces. In IRA-animals the renal: intestinal $\mathrm{Na}$ ratio was reversed, which finally resulted in a negative ileal digestibility for $\mathrm{Na}$ in IRA-pigs. 
Table 3. Sodium balances in pigs with ileo-rectal anastomosis (IRA), post-valve T-caecum $(P V T C)$ cannula or intact intestinal tract $\ddagger$

\begin{tabular}{|c|c|c|c|c|c|}
\hline Treatment group... & $\begin{array}{c}\text { Period } \\
\text { after surgery } \\
\text { (weeks) }\end{array}$ & IRA & PVTC & Intact & SEM \\
\hline$\ldots \ldots$ & $-\quad-\quad-$ & $-\ldots-\ldots$ & $\ldots \ldots$ & $\ldots \ldots$ & - - \\
\hline \multirow[t]{2}{*}{ Intake (mg) } & 5 & 3015 & $2078 * * *$ & $2160^{* * *}$ & 36.74 \\
\hline & 11 & 3314 & $2759 * * *$ & $2924 * * *$ & $46 \cdot 17$ \\
\hline \multirow{2}{*}{ Excretion in faeces ( $\mathrm{mg}) \$$} & 5 & 2319 & $512^{* * *}$ & $376^{* * *}$ & $100 \cdot 85$ \\
\hline & 11 & 3672 & $1065 * * *$ & $960^{* * *}$ & 161.33 \\
\hline \multirow[t]{2}{*}{ Fxeretion in urine $(\mathrm{mg})$} & 5 & 32 & $867 * * *$ & $1122 * * *$ & 66.79 \\
\hline & 11 & 48 & $1206 * * *$ & $1575+t$ & 87.57 \\
\hline \multirow[t]{2}{*}{ Retention (mg) } & 5 & 663 & 699 & 662 & 117.06 \\
\hline & 11 & -407 & $488^{* *}$ & $390^{* *}$ & $181 \cdot 48$ \\
\hline \multirow[t]{2}{*}{ Retention $(\%)$} & 5 & $21 \cdot 9$ & $33 \cdot 8$ & $30 \cdot 7$ & 4.43 \\
\hline & 11 & $-12 \cdot 4$ & $17.9 * *$ & $13 \cdot 3^{* *}$ & $5 \cdot 82$ \\
\hline \multirow[t]{2}{*}{ Total digestibility $(\%)$} & 5 & $23 \cdot 0$ & $75 \cdot 5^{* * *}$ & $82 \cdot 6^{* * *}$ & 3.61 \\
\hline & 11 & $-10 \cdot 9$ & $61 \cdot 4^{* * *}$ & $67 \cdot 2^{* * *}$ & $4 \cdot 99$ \\
\hline
\end{tabular}

Mean values were significantly different from those for IRA-pigs: $* * P<0.01, * * * P<0.001$.

Mean values for intact pigs were significantly different from those for PVTC-pigs and IRA-pigs: $+\dagger P<0.01$. For details of techniques and procedures, see pp. 306-307.

$\$$ In PVTC-pigs and in intact pigs, excretion in faeces; in IRA-pigs, excretion in digesta.

Table 4. Potassium balances in pigs with ileo-rectal anastomosis (IRA), post-valve T-caecum (PVTC) cannula or intact intestinal tract $\dagger$

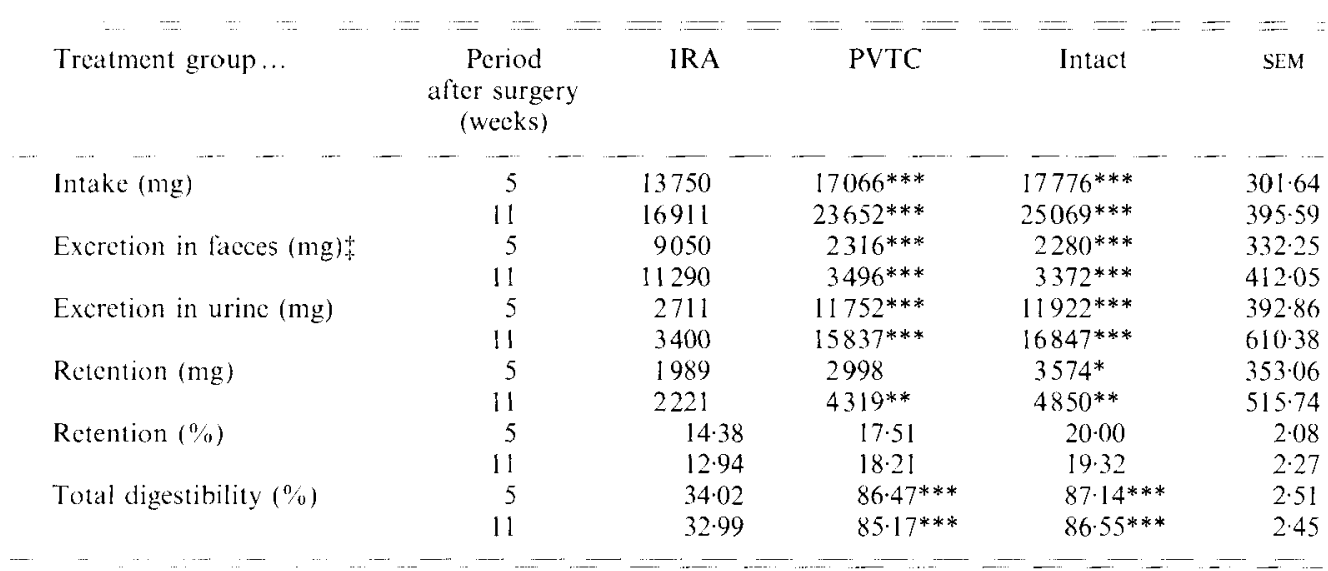

Mcan values were significantly different from those for IRA-pigs: ${ }^{*} P<0 \cdot 05,{ }^{*} P<0 \cdot 01 .{ }^{* * *} P<0.001$.

+ For details of techniques and procedures, see pp. 306-307.

† In PVTC-pigs and in intact pigs, excretion in faeces; in IRA-pigs, excretion in digesta.

\section{$K$ balance}

The $\mathrm{K}$ balances (Table 4) show differences similar to those for Na balances. The faecal apparent digestibility of $\mathrm{K}$ in the PVTC-cannulated and intact pigs was about $86 \%$. The intestinal utilization of $\mathrm{K}$ in IRA-pigs was $34 \%$. As for $\mathrm{Na}$, the renal:intestinal $\mathrm{K}$ loss in IRA-animals did not follow the pattern found for intact and PVTC-animals. The amount of $\mathrm{K}$ excreted in urine of intact and PVTC-pigs was higher than that excreted in the faeces $(P<0.001)$. In IRA-pigs more $\mathrm{K}$ was excreted in the digesta than in the urine. At 5 weeks after surgery $\mathrm{K}$ retention $(\mathrm{mg} / \mathrm{d})$ of IRA-pigs was lower $(P<0.05)$ than that of intact 
Table 5. Organ weights $\left(\mathrm{g} / \mathrm{kg}\right.$ live weight $\left.{ }^{(0.75}\right)$ of pigs with ileo-rectal anastomosis (IRA) or post-valve T-caecum $(P V T C)$ cannula in comparison with intact pigs of the same age 13 weeks after surgery $\dagger$

\begin{tabular}{|c|c|c|c|c|}
\hline Treatment group... & IRA & PVTC & Intact & SEM \\
\hline Liver & $13 \cdot 18$ & $12 \cdot 24$ & $12 \cdot 68$ & $1 \cdot 34$ \\
\hline Kidneys & $3 \cdot 40$ & $2 \cdot 80$ & $2 \cdot 72$ & 0.18 \\
\hline Adrenal glands (mg) & 93.00 & $60 \cdot 00^{* * *}$ & $53 \cdot 33^{* * *}$ & 0.01 \\
\hline Circumference of rectum $(\mathrm{mm})$ & $149 \cdot 4$ & $99 \cdot 3 * * *$ & $113 \cdot 3^{* * * *}$ & 68 \\
\hline
\end{tabular}

Mean values were significantly different from those for IRA-pigs: ${ }^{* * *} P<0.001$.

+ For details of techniques and procedures, see pp. 306-307.

Table 6. Creatinine content in blood of pigs

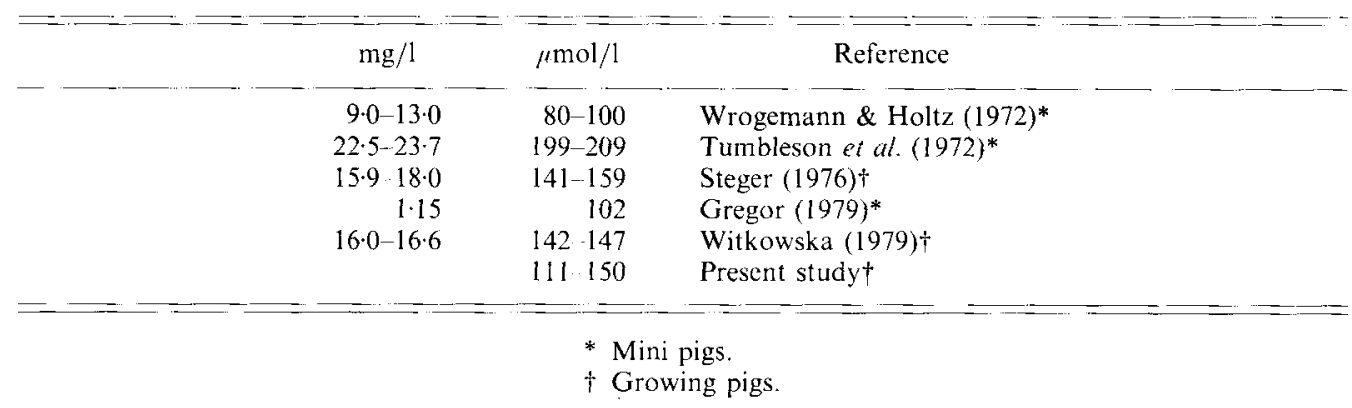

animals. At 11 weeks after surgery the $\mathrm{K}$ retention $(\mathrm{mg} / \mathrm{d})$ of PVTC- and intact animals was higher $(P<0.01)$ than that of IRA-pigs. $\mathrm{K}$ retention expressed as a percentage of intake shows no differences between the treatments.

\section{Organ weights}

Table 5 shows the relative weights of the liver, the kidneys and the adrenal glands at 13 weeks after surgery. Weights are expressed in $\mathrm{g} / \mathrm{kg}$ live weight ${ }^{0.75}$. For the IRA-pigs the weights of the organs were higher than for the other animals. For the adrenal glands these differences were significant $(P<0.001)$. In addition to the organ weights the circumference of the rectum was measured. In IRA-animals the circumference of the rectum was larger $(P<0.001)$ than that in PVTC- or intact animals.

\section{DISCUSSION}

Steger et al. (1976) reported that the blood creatinine content of growing pigs is positively correlated with the weight of the animals. In agreement with this statement, Duggal \& Eggum (1978) reported that the daily creatine and creatinine excretion of growing pigs was positively related to body-weight and to nitrogen retention. In addition, Murlin et al. (1953) concluded from their results that high urinary creatinine excretion indicated high $\mathrm{N}$ utilization. It may be assumed from these three studies that high blood creatinine content may be associated with high urinary creatinine excretion; furthermore it may also be related to high $\mathrm{N}$ utilization and high muscle mass. Only a limited amount of information is available in the literature on blood creatinine levels of pigs. These findings are summarized in Table 6 . The present results, which were in the range 111-149 $\mu \mathrm{mol} / 1$ (Table 2 ), are in agreement with corresponding values from the literature. 
Table 7. Urea content in blood of pigs

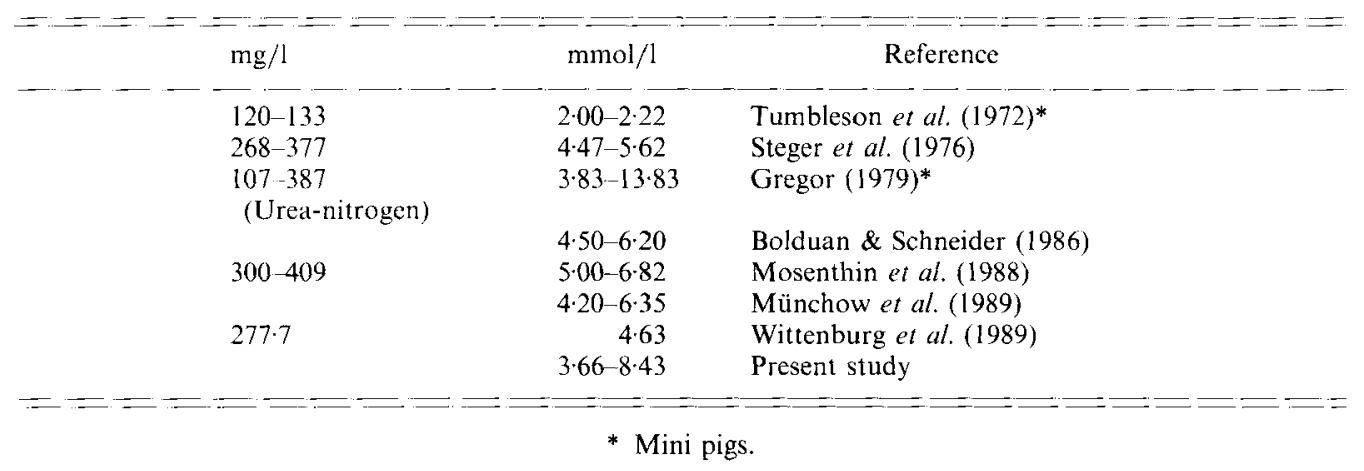

A lower creatinine concentration $(P<0.01)$ and lower daily live weight gain $(P<0.01)$ was found for IRA-pigs than for PVTC- and intact pigs. The IRA-pigs also showed a lower $\mathrm{N}$ retention $(P<0.001$; Köhler et al. 1992b). Thus, our findings for IRA-pigs were in accordance with values from the literature for pigs with a reduced live weight, daily live weight gain and $\mathrm{N}$ utilization.

Berschauer (1977) found a clear negative correlation between the extent of protein utilization and blood urea content. Berschauer (1977) measured blood urea in pigs fed on diets differing in energy: protein ratio and concluded that an energy deficiency results in higher blood urea concentrations.

Bolduan \& Schneider (1986) reported that the normal blood urea content of pigs ranges from 4 to $7 \mathrm{mmol} / 1$ serum. About $90 \%$ of urea is derived from deamination of amino acids after absorption and $10 \%$ is derived from ammonia originating from microbial activity and subsequent deamination in the intestine. Blood urea contents reported in the literature are given in different units of measurement. Table 7 gives a brief summary of these results as well as the corresponding values expressed in $\mathrm{mmol} / \mathrm{l}$. Our values are in the same range as those reported in the literature. There were significant differences $(P<0.001)$, however, between the treatments in our experiment (Table 2).

The blood urea content also depends on: (a) potential rate of protein gain (breed, sex, age); (b) protein quality (the composition of the amino acids); (c) level of protein intake; (d) energy intake. In the present experiment all these factors were standardized by assessing feed intake on a unit metabolic body-weight basis. The blood urea content of intact pigs and PVTC-cannulated pigs increased with time. This is possibly related to $\mathrm{N}$ retention and growth intensity which decreased with time (Köhler et al. 1992b). In IRA-pigs the blood urea content during the 6 th week after surgery was higher $(P<0.001)$ than that in intact or PVTC-cannulated pigs. These findings are in accordance with both the reduced $\mathrm{N}$ retention and growth in the IRA-pigs. Rerat (1986) concluded that in intact pigs the amount of urea which is taken up by the intestinal tract and excreted as microbial protein in the faeces was similar to the urinary excretion of urea. This recycled urea is excreted as microbial protein in the faeces. For pigs fitted with an IRA, urea excretion as microbial protein is assumed impossible unless there is compensatory fermentation in the distal ileum or in the rectum, or both. Urea could also be excreted unchanged in ileal digesta, because Mosenthin et al. (1988) reported a higher urea concentration in ileal digesta after intravenous infusion of urea. Additional findings (T. Köhler, M. W. A. Verstegen and R. Mosenthin, unpublished results) showed that the $\mathrm{N}$ content of digesta from IRA-pigs was higher than that of ileal digesta from PVTC-pigs. Thus, the composition of ileal digesta 
from IRA-animals is not similar to that of PVTC-animals. Also, the amounts of volatile fatty acids and diaminopimelic acid (DAPA) in the digesta of IRA-pigs were increased and were higher $(P<0.05$ and $P<0.001$ respectively) than those in PVTC-animals (Köhler $e t$ al. 1992b). This shows that there is increased microbial activity in the ileum or rectum, or both, in IRA-pigs. As a consequence more $\mathrm{N}$ might be excreted because some urea may have been utilized by micro-organisms. This could also explain the higher $(P<0.001)$ concentration of $\mathrm{N}$ in the digesta of the IRA-animals compared with the PVTC-pigs. It may indicate a compensatory change of function in the ileum or rectum, or both, in the IRA-animals. A compensatory change in digestive function in IRA-pigs was also suggested by values obtained for the dry matter contents of the digesta. The ileal dry matter content for IRA-animals was higher $(P<0.001)$ than that of ileal digesta for PVTC-pigs (Köhler et al. $1992 a)$. In addition to these findings, the larger $(P<0.001)$ circumference of the rectum (Table 5) and the irregular digesta outflow (Köhler et al. 1992b) indicate an increased transit time for digesta in the rectum. This may result in extra water absorption.

Alcantara et al. (1980) reported that pigs fed on a low- $\mathrm{Na}$ diet had a low blood $\mathrm{Na}$ concentration and also had an increased blood $\mathrm{K}$ concentration. There are reports that the ileal digestibility of $\mathrm{Na}$ is negative and that $\mathrm{Na}$ is absorbed in the large intestine (Partridge, 1978; Drochner, 1984; Partridge et al. 1986; Den Hartog et al. 1988). In IRA-pigs, in the absence of absorption from the large intestine, lower utilization of $\mathrm{Na}$ from the feed can be assumed, i.e. the absence of $\mathrm{Na}$ absorption in the large intestine may have the same effects as a low-Na diet. This would explain the lower $(P<0.001$ and $P<0.01) \mathrm{Na}$ concentration in the blood of IRA-pigs at 6 and 13 weeks after surgery respectively (Table 2). In addition, the blood $\mathrm{K}$ concentration of IRA-pigs was higher than those of the other treatments. Hyperkalaemia has been reported as a typical manifestation of Na deficiency (Black, 1960). Our findings in IRA-animals show the same tendencies as those reported by Alcantara et al. (1980) who fed low-Na diets. Münchow et al. (1989) reported serum Cl concentrations in the range $97 \cdot 0-104.0 \mathrm{mmol} / 1$ for pigs fed on different diets. In accordance with these values, our findings $(91.9-99.9 \mathrm{mmol} / \mathrm{l})$ were in the same range and they did not differ between treatments. Hennig et al. $(1986,1988)$ reported Ca concentrations in serum of intact and anastomosed pigs in the range 2.59-2.94 mmol/1 and Münchow et al. (1989) reported $2 \cdot 52-2 \cdot 73 \mathrm{mmol} \mathrm{Ca} / \mathrm{l}$ serum. In the present experiment similar $\mathrm{Ca}$ concentrations were found with no differences between treatments.

For $\mathrm{Mg}$ there were no differences between the groups and the results were comparable with values reported in the literature. Nuoranne (1983) reported a normal post-absorptive $\mathrm{Mg}$ concentration of $0.80-0.96 \mathrm{mmol} / 1$ serum; this is in accordance with our values $(0 \cdot 83-0.90 \mathrm{mmol} / \mathrm{l})$.

The IRA-technique had a considerable effect on the base excess and the bicarbonate concentration; both variables were lower $(P<0.01$ and $P<0.001$ respectively) in pigs provided with an IRA. Patience $e t$ al. (1987) reported that reducing the dietary electrolyte balance decreased the serum $\mathrm{pH}$ and bicarbonate concentration of pigs. In accordance with these findings IRA-animals had a lower $(P<0.01)$ blood pH 13 weeks after surgery. Based on these findings a metabolic acidosis as a result of the reduced electrolyte balance can be expected for IRA-pigs. Findings for PVTC-cannulated pigs were similar to those for intact pigs.

In IRA-animals a significantly lower growth and $\mathrm{N}$ retention were observed (Köhler et al. $1992 \mathrm{~b}$ ). Growth, $\mathrm{N}$ retention and protein utilization depend on the level of energy intake. $\mathrm{Na}$ is an important element in the active absorption of different nutrients. Therefore, negative absorption of $\mathrm{Na}$ may be detrimental to the rate of gain. To compensate for the negative $\mathrm{Na}$ balance the IRA-pigs were supplied orally with extra electrolyte solution mixture, as described by Hennig et al. (1986). In addition, these authors 
Table 8. Sodium contents in urine $(\mathrm{mg} / \mathrm{l}) 5$ and 11 weeks after surgery in pigs with ileo-rectal anastomosis (IRA), post-valve T-caecum (PVTC) cannula or intestinal intact tract*

\begin{tabular}{|c|c|c|c|c|c|}
\hline$=-$ & $\begin{array}{c}\text { Treatment group ... } \\
\text { Period after surgery } \\
\text { (weeks) }\end{array}$ & IRA & PVTC & Intact & SEM \\
\hline & 5 & $15 \cdot 00^{a}$ & $371 \cdot 60^{\mathrm{b}}$ & $41600^{b}$ & $17 \cdot 70$ \\
\hline & 11 & $12 \cdot 38^{\mathrm{a}}$ & $336 \cdot 00^{h}$ & $406.83^{\circ}$ & 17.67 \\
\hline
\end{tabular}

:t.b.l Mean values in the same row with unlike superscript letters were significantly different $P<0.001$.

* For details of techniques and procedures, see pp. 306-307.

Table 9. Sodium contents in ileal digesta ( $\mathrm{g} / \mathrm{kg}$ dry matter) 3,9 and 12 weeks after surgery in pigs with ileo-rectal anastomosis (IRA) or post-valve T-caecum (PVTC) cannula

\begin{tabular}{cccc}
\hline \hline $\begin{array}{c}\text { Treatment group ... } \\
\text { Period after surgery } \\
\text { (wecks) }\end{array}$ & IRA & PVTC & SEM \\
\hline 3 & $10 \cdot 2$ & $30 \cdot 0^{*}$ & $0 \cdot 7$ \\
9 & $9 \cdot 6$ & $28 \cdot 4^{*}$ & $0 \cdot 6$ \\
12 & $9 \cdot 5$ & $31 \cdot 9^{*}$ & $0 \cdot 4$ \\
\hline
\end{tabular}

Mean values were significantly different from those for IRA-pigs: ${ }^{*} P<0 \cdot 001$.

proposed a sugar-starch supplement for IRA-animals to compensate for the absence of energy absorption from the large intestine. They reported similar $\mathrm{N}$ utilization and $\mathrm{N}$ balance in IRA-pigs and intact pigs (Hennig, 1988). In the present investigation an electrolyte solution mixture, as described by Hennig et al. (1986), was added to the diet ( $200 \mathrm{ml} / 20 \mathrm{~kg}$ live weight per d), but the sugar-starch supplement was not provided. Our findings showed that the addition of the electrolyte solution to the diet of the IRA-pigs was not sufficient to achieve the same level of $\mathrm{N}$ retention as intact or PVTC-cannulated animals. In IRA-pigs Na metabolism in the absence of the large intestine was different from that of the other groups (Table 3). Faecal Na digestibility of the intact and PVTCcannulated pigs ranged from 61.4 to $82.6 \%$. In IRA-pigs total Na digestibility was 23.0 and $-10 \cdot 9 \%$. Clarke et al. (1967) reported chronic Na depletion in humans fitted with an ileostomy. Their investigation by means of intravenous saline $(9 \mathrm{~g}$ sodium chloride/l) infusion revealed an intestinal adaptation to conserve $\mathrm{Na}$. Thus, after $\mathrm{Na}$ infusion $\mathrm{Na}$ concentration in ileal digesta increased and $\mathrm{K}$ concentration decreased. This post-infusion response suggests $\mathrm{Na}$ conservation in exchange for $\mathrm{K}$. In our experiment $\mathrm{Na}$ loss in the urine was lowest in IRA-pigs. To compensate for the absence of Na absorption in the large intestine of IRA-pigs the urinary $\mathrm{Na}$ loss was about thirty times lower than that in intact pigs (Table 8). In humans Clarke et al. (1967) concluded that intestinal adaptation is mediated by aldosterone. Increased aldosterone secretion may result in compensatory growth of the adrenal glands. In addition, kidney weights may have increased as the result of increased $\mathrm{Na}$ re-absorption. Table 5 shows that in IRA-animals weights of kidneys $(P>0.05)$ and adrenal glands were higher $(P<0.001)$ than those in PVTC- or intact animals. Values for PVTC-animals were similar to those for intact animals. The Na content of digesta from IRA-pigs was lower than that of PVTC-cannulated animals $(P<0.001)$ (Table 9). The low Na content of urine and ileal digesta was accompanied by a low blood 
$\mathrm{Na}$ concentration in IRA-pigs. The available information indicates that animals fitted with an IRA may have altered $\mathrm{Na}$ metabolism. It seems that these animals have a hydroelectrolyte disturbance due to the bypass of the colon.

For $\mathrm{K}$ a similar pattern was found (Table 4). The retention and the faecal: urinary $\mathrm{K}$ excretion of PVTC-cannulated pigs was comparable to that of intact pigs. There was a considerable change in these variables for anastomosed animals. Thus, IRA-pigs compensate for the absence of $\mathrm{K}$ absorption in the large intestine by reducing urinary excretion. The patterns of both $\mathrm{Na}$ and $\mathrm{K}$ balances demonstrate the important role of the large intestine in mineral absorption and were in agreement with the findings of Clarke et al. $(1967)$.

In conclusion, the findings of our experiment suggest that PVTC cannulation has no effect on the mineral balances, organ weights and blood variables measured. Differences between PVTC-pigs and intact pigs with regard to blood urea concentrations suggested an effect of digesta collection on this variable. Further studies are necessary to investigate the effect of digesta collection on urea metabolism in PVTC-pigs. For IRA-pigs the findings suggest that $\mathrm{Na}$ supplementation as carried out in the present experiment was insufficient to compensate for the absence of mineral absorption from the large intestine.

Financial support was partly provided by the H. Wilhelm Schaumann Foundation for Agrarian Sciences promotion. The authors also acknowledge the assistance of Piet van Leeuwen, Marja Kik, Gert Priem and Tamme Zandstra.

\section{REFERENCES}

Agricultural Research Council (1981). The Nutrient Requirements of Pigs. Slough: Commonwealth Agricultural Bureaux.

Alcantara, P. F., Hanson, L. E. \& Smith, J. D. (1980). Sodium requirements, balance and tissue composition of growing pigs. Joumal of Animal Science 50, 1092-1101.

Berschauer, F. (1977). Hohenheimer Arbeiten no. 91. Stuttgart: Verlag Eugen Ulmer.

Black, D. A. K. (1960). Current concepts of potassium metabolism. Journal of Pediatrics $\mathbf{5 6}, 814$.

Bolduan, G. \& Schneider, R. (1986). Einflüsse auf die Blutharnstoff-Konzentration beim Schwein (Factors affecting urea concentration in the blood of swine). Monatshefte für Veterinärmedizin 41, 524-527.

Clarke, A. M., Hill, G. L. \& Macbeth, W. A. A. G. (1967). Intestinal adaptation to salt depletion in a patient with an ileostomy. Gastroenterology 53, 444-449.

Den Hartog, L. A., Huisman, J., Thielen, W. J. G., van Schayk, G. H. A., Boer, H. \& van Weerden, E. J. (1988). The effect of including various structural polysaccharides in pig diets on ileal and faecal digestibility of amino acids and minerals. Livestock Production Science 18, 157-170.

Drochner, W. (1984). Einfluß wechselnder Rohfaser- und Pektingehalte im Futter auf einige praecaecale und postileale Verdauungsvorgänge beim wachsenden Schwein (Effect of varying amounts of crude fibre and pectin in feed on some pre-caecal and post-ileal digestive processes in growing pigs). Fortschritte in der Tierphysiologie und Tierernährung 14, Hamburg, Germany: Verlag Paul Parey.

Duggal, S. K.\& Eggum, B. O. (1978). Urinary creatinine and creatine excretion in pigs in relation to body weight and nitrogen balance. Journal of the Science of Food and Agriculture 29, 683-688.

Green, S. (1988). A note on amino acid digestibility measured in pigs with pre- or post-valve ileo-rectal anastomosis, fed soy-bean, pea and meat meal. Animat Production 47, 317-320.

Gregor, G. (1979). Hämatologische und biochemische Untersuchungen am Miniaturschwein MINI-LEWE. 3. Mitteilung: Fettstatus und Stoffwechselendprodukte (Haematological and biochemical observations in minipigs MINI-LEWE). Zeitschrift für Versuchstierkunde 21, 234-242.

Hennig, U. (1988). Natrium-Versorgung des Schweines bei Ausschaltung der Verdauung im Dickdarm (Sodium supply of pigs after elimination of hind-gut digestion). In Arbeitstagung Mengen- und Spurenelemente, pp. 199-206. Leipzig, Germany: University of Leipzig.

Hennig, U., Noel, R., Herrmann, U., Wünsche, J. \& Mehnert, E. (1986) Ernährungsphysiologische Untersuchungen an Schweinen mit Ileo-Rektal-Anastomosen. 1. Mitteilung: Operationsmethodik, biochemische und morphologische Befunde (Nutritional-physiological studies in pigs with ileo-rectal anastomosis. 1. Operation methods, biochemical and morphological findings). Archiv für Tierernährung 36, 585-596.

Hennig, U., Wünsche, J., Kreienbring, F., Mehnert, E.\& Hermann, U. (1988). Ernährungsphysiologische Untersuchungen an Schweinen mit Ileo-Rektal-Anastomosen. 2. Mitteilung: Einfluß von Nourseothricin auf Nährstoffverdaulichkeit, Aminosäurenresorption, Proteinverwertung und Mineralstoffbilanz einer Roggenration (Nutritional-physiological studies in pigs with ileo-rectal anastomosis. 2. Effect of Nourseothricin on 
nutrient digestibility, amino acid absorption and mineral balance of a rye diet). Archiv für Tierernälrung 38 , 585-601.

Köhler, T., Huisman, J., Den Hartog, L. A. \& Mosenthin, R. (1990). A comparison of different digesta collection methods to determine the apparent digestibilities of the nutrients at the terminal ileum in pigs. Journal of the Science of Food and Agriculture 53, 465-475.

Köhler, T., Den Hartog, L. A., Huisman, J., Mosenthin, R. \& Verstegen, M. W. A. (1992a). Digestibility measurements in pigs by using post-valve T-caecum cannulation or end-to-side ileo-rectal anastomosis. Journal of Animal Physiology and Animal Nutrition (In the Press).

Köhler, T., Mosenthin, R., Verstegen, M. W. A., Huisman, J., Den Hartog, L. A. \& Ahrens, F. (1992b). Effect of ileorcetal anastomosis and post-valve T-caecum cannulation on growing pigs. 1. Growth performance, $\mathrm{N}$ balance and intestinal adaptation. British Journal of Nutrition 68, 293-303.

Laplace, J. P., Darcy-Vrillon, B., Perez, J. M., Henry, Y., Giger, S. \& Sauvant, D. (1985). Associative effects between two fibre sources on ileal and overall digestibilities of amino acids, energy and cell-wall components in growing pigs. British Journal of Nutrition 61, 75-87.

Mosenthin. R., Mauritz-Boeck, I., Henkel, H., Sauer, W. C. \& Ozimek, L. (1988). The effect of the level of fermentation in the large intestine on urea recycling in pigs. Proceedings of the 5 th International Symposium on Protein Metabolism and Nutrition. European Association of Animal Production Publication No. 35, pp. 30 -31. Rostock, Germany: University of Rostock.

Münchow, H., Häger, H., Hasselmann, L. \& Finger, M. (1989). Untersuchungen zur Fütterung verschieden behandelter Strohmaterialien an Ferkeln nach traditionellem Absatztermin (Comparative studies of the applicability of variously treated straw materials in the feeding of piglets after the traditional weaning date). Archiv für Tierernährung 39, 299-309.

Murlin, J. R., Hayes, A. D. \& Johnson, K. (1953). Correlation between the biological value of protein and the percentage of creatinine $\mathrm{N}$ in the urine. Journal of Nutrition 51, 149-161.

Nuoranne, P. J. (1983). On the effect of food magnesium level on serum magnesium, molar Mg:Ca and potassium value in pigs. Nordisk Veterinarmedicin 35, 219-232.

Partridge, I. G. (1978). Studies on digestion and absorption in the intestines of growing pigs. 3. Net movements of mineral nutrients in the digestive tract. British Journal of Nutrition 39, 527-545.

Partridge, I. G., Simon, O. \& Bergner. H. (1986). The effects of treated straw meal on ileal and faecal digestibility of nutrients in pigs. Archiv für Tierernährung 36, 351-359.

Patience, J. F., Austic, R. E. \& Boyd, R. D. (1987). Effect of dietary electrolyte balance on growth and acid-base status in swine. Joumal of Animal Science 64, 457-466.

Picard, M.. Bertrand, S., Genin, F. \& Maillard, R. (1984). Digestibilité des acides aminés: intérêt de la technique du shunt ileo-rectal chez le porc (Digestibility of amino acids: advantages of the ileo-rectal shunt technique in pigs). Journies de la Recherche Porcine en France 16, 355-360.

Rerat, A. (1986). Postprandial quantitative kinetics of urea and ammonia nitrogen exchanges between the digestive tract and the portal blood in conscious pigs receiving a diet with or without urea. Archiv für Tierernährung 36, 252-269.

Souffrant, W. B., Schumann, B., Matkowitz, R. \& Gebhardt, G. (1985). Untersuchungen zur Stickstoff- und Aminosäurenresorption im Dünndarm von wachsenden Schweinen (Studies on the absorption of nitrogen and amino acids in the small intestine of growing pigs). Archiv für Tierernährung 11, 781-789.

Steger, H.. Otto, E., Rommel, P., Püschel, F., Blödow, G. \& Schill, G. (1976). Biochemische Kennwerte als Selektionsmerkmal. 2. Mittcilung: Untersuchungen an MPA-Schweinen (Biochemical indices as selection trait). Archiv für Tierzucht 19, 321-339.

Tumbleson, M. E., Badger, T. M., Baker, P. C. \& Hutcheson, D. P. (1972). Systematic oscillations of serum biochemic and hematologic parameters in sinclair (S-I) miniature swine. Journal of Animal Science 35, 48-50.

van Lecuwen, P., Huisman, J., Verstegen, M. W. A., Baak, M. J., van Kleef, D. J., van Weerden, E. J. \& Den Hartog, L. A. (1988). A new technique for collection of ileal chyme in pigs. In Proceedings of the IVth International Symposium on Digestive Physiology in the Pig, pp. 289 296 [L. Buraczewski, S. Buraczewska, B. Pastuszewska and T. Zebrowska, editors]. Jablonna, Poland: Polish Academy of Science.

van Leeuwen, P., van Kleef, D. J., van Kempen, G. J. M., Huisman, J. \& Verstegen, M. W. A. (1991). The post valve T-caecum cannulation technique in pigs applied to determine the digestibility of amino acid in maize, groundnut and sunflower meal. Joumal of Animal Physiology and Animal Nutrition 65, 183-193.

Willis, J. B. (1960). Determination of calcium in blood serum by atomic absorption spectroscopy. Nature 186, $249-250$.

Wittenburg, H., Jentsch, W., Hennig, U., Kreienbring, F. \& Krause, S. (1989). Untersuchungen zum Energieerhaltungsbedarf wachsener Schweine verschiedenen Geschlechts bei normalen und hohen Proteingaben (Studies of the energy maintenance requirement of growing pigs of both sexes with normal and high protein supply). Archiv für Tierernälrung 39, 263-287.

Witkowska, A. (1979). Kreatyna I Kreatynina W Surowicy Krwi I Mieśniach Swin Otrzymujacych Dawki Pokarmowe O Roznej Zawartosei Bialka (Creatine and creatinine in the blood serum and muscles of pigs fed on rations of different protein levels). Roczniki Nauk Rolniczych 100, 69-79.

Wrogemann, J. \& Holtz, W. (1977). Blutuntersuchungen am Göttinger Miniaturschwein (Studies of blood variables in minipigs). Zeitschrift für Versuchstierkunde 19, 276-289. 